\title{
Crystal structure of paralaurionite and its OD relationships with laurionite
}

\author{
S. Merlino, M. Pasero and N. Perchiazzi \\ Dipartimento di Scienze della Terra, Università di Pisa, Via S. Maria 53, I-56126 Pisa, Italy
}

\begin{abstract}
The crystal structure of the rare lead hydroxychloride paralaurionite $[\mathrm{PbCl}(\mathrm{OH})$, monoclinic, space group $\left.C 2 / m, a=10.865(4), b=4.006(2), c=7.233(3) \AA, \beta=117.24(4)^{\circ}\right]$ has been refined to $R=$ $0.062, R_{\mathrm{w}}=0.048$. Its Order-Disorder (OD) character and its OD relationships with the orthorhombic polytpe of $\mathrm{PbCl}(\mathrm{OH})$, laurionite, are discussed. Laurionite and paralaurionite represent the two MDO structures within a family of OD structures built up by two different kinds of layers. The structures of paralaurionite and laurionite are compared thoroughly. The first coordination of the various atoms in the two polytypes is the same, however, remarkable differences exist in the connection between adjacent $\mathrm{Pb}$-centred polyhedra.
\end{abstract}

KEYwORDS: OD structures, paralaurionite, lead hydroxychlorides, laurionite, Baratti, Italy.

\section{Introduction}

Two distinct mineral species exist with the same simple chemical formula $\mathrm{PbCl}(\mathrm{OH})$, namely laurionite and paralaurionite. Both minerals were first discovered in the ancient metallurgical slags of Laurion, Greece. The former was described by Köchlin (1887) and vom Rath (1887), whereas the latter was identified by Smith (1899a).

Both minerals were also reported from the Wheal Rose mine, near Sithney, Cornwall, U.K. (Russell, 1928). Moreover paralaurionite has been found in the Mammoth mine, Tiger, Arizona, U.S.A. (Palache, 1950), and in the San Rafael mine, Sierra Gorda, Chile (Arzruni and Thaddéeff, 1899). In the latter occurrence, the mineral was indicated as rafaelite, but shortly thereafter it has been proven to be identical to paralaurionite (Smith, 1899b).

The crystals of paralaurionite used in this study were sampled at Baratti beach, southern Tuscany, Italy. Baratti is a newly discovered mineralogical locality, where paralaurionite occurs in Etruscan iron slags together with laurionite and a number of lead and copper oxy- and hydroxychlorides, sulphates and carbonates (Franzini et al. , 1992).

All published chemical analyses (cf. Palache et al., 1951) indicate unambiguously the chemical formula $\mathrm{PbCl}(\mathrm{OH})$ for both laurionite and paralaurionite.

\section{X-ray crystallography}

A morphological study of paralaurionite from Laurion (Palache, 1934) indicated the monoclinic symmetry and the very common twinning on (100). Single crystal X-ray diffraction study confirmed that paralaurionite is monoclinic, space group $C 2 / m, a=10.77, b=3.97, c=7.18 \AA, \beta=$ $117.2^{\circ}$ (Palache, 1950). On the other hand laurionite is orthorhombic, space group Pcmn, $a=9.7$, $b=4.05, c=7.1 \AA$ (Goldsztaub, 1937). The close metrical relationships between the two minerals are evident, $b$ and $c$ being almost identical, and being $a_{o} \cong a_{m} \sin \beta_{m}$, where the subscripts refer to the orthorhombic and monoclinic phases, respectively.

A number of structural determinations and refinements have been presented for laurionite. Goldsztaub (1937, 1939) and Brasseur (1940) proposed a plausible structural model for the mineral, in which, however, the oxygen was incorrectly placed, and the position of chlorine was poorly defined. Cannillo et al. (1969) and Venetopoulos and Rentzeperis (1975) independently refined the structure of laurionite and presented very similar structural parameters. In 
contrast, structural studies of paralaurionite were never carried out.

\section{OD character of laurionite and paralaurionite}

The structural relationships between orthorhombic laurionite and monoclinic paralaurionite may be appreciated, and a reliable structural model for the latter may be obtained, on the basis of the OD theory (Dornberger-Schiff, 1964, 1966).

The structure of the orthorhombic phase can be described conveniently as consisting of two different layers which alternate regularly (Fig. 1). Both layers have the same $\mathbf{b}$ and $\mathbf{c}$ translation periods. Layers $\mathrm{L}_{2 n}$ are formed by $\mathrm{Pb}$ atoms and $\mathrm{OH}$ groups and display the layer group symmetry $P$ (1) $21 / m 1$, where the brackets around the symbol 1 indicate that $\mathbf{a}$ is the direction of missing periodicity of the layer. Layers $\mathrm{L}_{2 n+1}$ are formed by $\mathrm{Cl}$ atoms only and display the layer group symmetry $P(2 / c) 2 / m 2 / m$ (Fig. 2$)$. In that structure $L_{2 n}$ and $L_{2 n+2}$ layers are related through the $c$ glide parallel to (100) and through the $2{ }_{1}$ screw axes parallel to $\mathbf{c}$, both symmetry operators of the $\mathrm{L}_{2 n+1}$ layers. If we look at Fig. 2

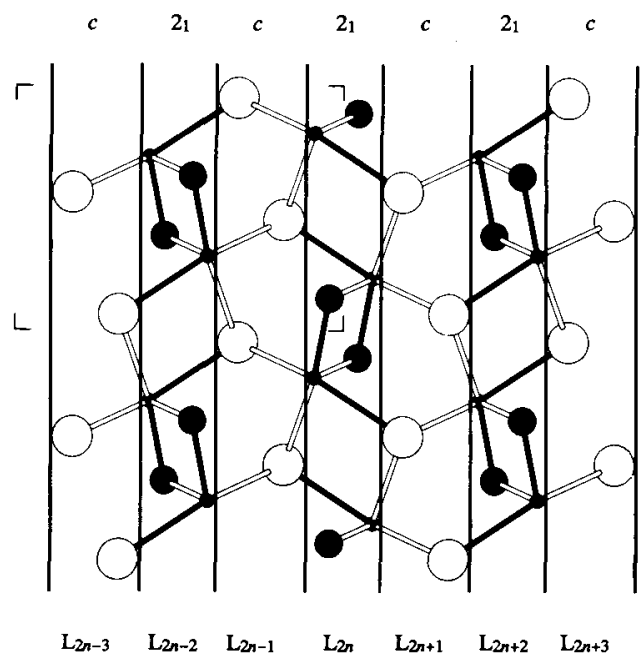

FIG. 1. The crystal structure of laurionite as seen along [010]. Small, medium and large circles, as well as different shadings, indicate $\mathrm{Pb}, \mathrm{O}$ and $\mathrm{Cl}$, respectively. Hydrogen atoms are not indicated. The unit cell limits are outlined. The symmetry operators active in the different layers are also given $\left(\mathrm{MDO}_{1}: c 2_{1} c 2_{1} \ldots\right)$. All atoms lie on symmetry planes at either $y=0$ or $y=1 / 2$. Empty sticks denote a single interatomic bond between atoms at the same $y$ level, whereas filled sticks denote double bonds with two atoms lying on opposite neighbouring planes.

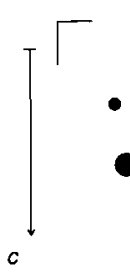

P (1) $2 / m 1$

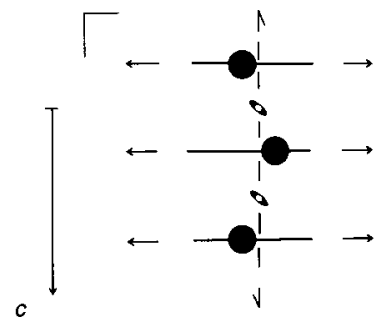

$P(2 / c) 2 / m 2, / m$
Fig. 2. The two kinds of OD layers occurring in laurionite and paralaurionite with their layer group symmetry. Small, medium and large circle indicate $\mathrm{Pb}$, $\mathrm{O}$ and $\mathrm{Cl}$, respectively. Open and filled circles denote the different heights of the atoms, which lie on symmetry planes displaced by $y / 2$.

we realise that $L_{2 n}$ and $L_{2 n+2}$ layers may be related also through different symmetry operators in the $\mathrm{L}_{2 n+1}$ layers, namely twofold axes parallel to $\mathbf{b}$ and inversion centres. Therefore an infinite number of structures is possible, corresponding to the possible sequences of operators (either $c$ glide and $2_{1}$ screw axes or twofold axes and inversion centres) that may be active in $\mathrm{L}_{2 n+1}$ layers. Pairs of adjacent layers are geometrically equivalent in both cases and those structures must be considered as belonging to one family of OD structures consisting of two distinct kinds of layers (Dornberger-Schiff, 1964).

The relation between $\mathrm{Cl}$ layers $\mathrm{L}_{2 n-1}$ and $\mathbf{L}_{2 n+1}$ is always the same; they are related through the $2{ }_{1}$ screw axes parallel to $b$ and the inversion centres which are symmetry operators of the $\mathrm{L}_{2 n}$ layers.

The symmetry properties common to the whole OD family, consisting of all possible polytypes as well as the one-dimensionally disordered structures, are comprehensively described by the OD groupoid family symbol:

$$
P(1) 2{ }_{1} / m 1 \quad P(2 / c) 2 / m 21 / m
$$

$[1 / 4,0.1936 .$.

in which, according to the statements of the theory for OD structures built up by two kinds of layers, the first line contains the layer group symbols of both layers, and the second indicates the positional relations between adjacent layers (Grell and Dornberger-Schiff, 1982).

Among the infinite possible polytypes, OD theory singles out those with maximum degree of order, the so called MDO structures, namely those structures that contain the smallest number of different kinds of layers (Dornberger-Schiff, 1982; Dornberger-Schiff and Grell, 1982). 
According to the preceding discussion, in the present case only one kind of $\left(\mathrm{L}_{2 n-2} ; \mathrm{L}_{2 n} ; \mathrm{L}_{2 n+1}\right)$ triple is possible, whereas two different $\left(\mathrm{L}_{2 n}\right.$; $\left.\mathrm{L}_{2 n+1} ; \mathrm{L}_{2 n+2}\right)$ triples are possible. As a consequence the smallest number of different triples necessary to build a periodic polytype is two, from which it follows that two MDO polytypes only occur in this family. The first one, obtained when $c$ glide and 21 screw axes are constantly active in Cl layers $L_{2 n+1}$, has space group symmetry Pcmn and corresponds to the structure of laurionite $\left(\mathrm{MDO}_{1}\right.$; Fig. 1); the second one, obtained when twofold axes parallel to $\mathbf{b}$ and inversion centres are constantly active in $\mathrm{Cl}$ layers $\mathrm{L}_{2 n+1}$, has space group symmetry $C 2 / m$ and unit cell parameters corresponding to those obtained for paralaurionite $\left(\mathrm{MDO}_{2}\right.$; Fig. 3).

Closely similar cases of OD families built up by two kinds of layers, with monoclinic and orthorhombic MDO structures, have been already described: among others yttrium hydroxychloride (Dornberger-Schiff, 1967), stibivanite (Merlino et al., 1989), zoisite-clinozoisite (Merlino, 1990).

\section{Crystal structure analysis}

A crystal (dimensions $0.375 \times 0.075 \times 0.05$ $\mathrm{mm}$ ) of paralaurionite from Baratti was chosen for the intensity data collection, which was carried out on an ITAL STRUCTURES four-circle diffractometer using graphite-monochromated Mo $K \alpha$ radiation. Preliminary Weissenberg photographs exhibited Laue symmetry and systema-

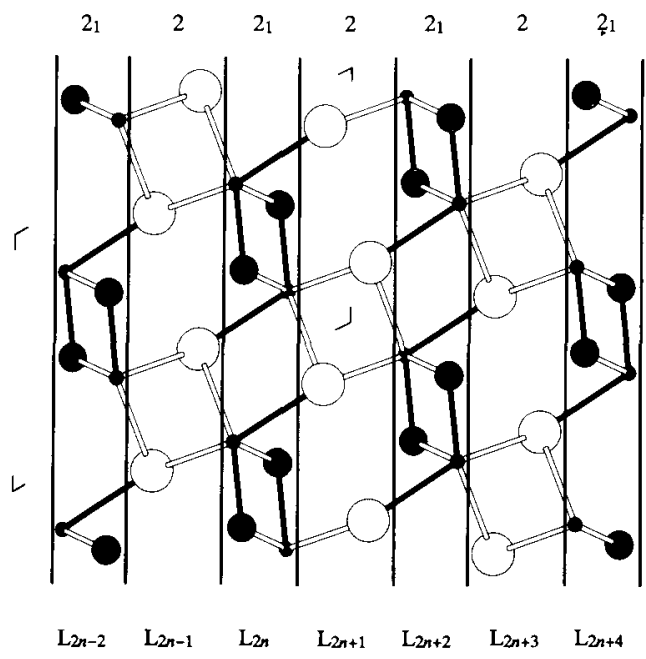

Fig. 3. The crystal structure of paralaurionite as seen along [010]. The symmetry operators active in the different layers are given $\left(\mathrm{MDO}_{2}: 22_{1} 22_{1} \ldots\right)$. See also caption to Fig. 1. tic absences consistent with the space groups $C 2 / m, C 2$ and $C m$. The first was assumed as the correct one, on the basis of the OD approach. The correctness of that choice has been confirmed by the excellent refinement. All tested crystals were twinned, with (100) as twin plane. The common occurrence of twinning in crystals of paralaurionite may be explained, according to the OD theory, as due to faults in the sequence of symmetry operators which should be constantly active in $\mathrm{L}_{2 n+1}$ layers of the $\mathrm{MDO}_{2}$ polytype, namely to substitutions of two-fold axes by $c$ glide (symmetry operator constantly active in $L_{2 n+1}$ layers of the $\mathrm{MDO}_{1}$ polytype). The metrical relationships between reciprocal parameters of the two twin individuals caused reflections with $l=8 n$ to be almost exactly superimposed, whereas reffections of the first individual with $l=8 n \pm 3$ were at the reciprocal distance of about $0.013 \AA^{-1}$ from reflections of the second individual. Therefore it was decided to leave out all these reflections from the least-square calculations, it being impossible to resolve them in the intensity data collection. Of the 827 measured intensities $\left[\omega-2 \theta\right.$ scan mode, $2 \theta_{\max }=60^{\circ}$, scan range in $\theta \pm$ $\left(0.8^{\circ}+0.15^{\circ} \tan \theta\right)$, minimum scan speed $1^{\circ}$ $\left.\min ^{-1}\right], 515$ fulfilled the requirement of having $l \neq$ $8 n$ and $l \neq 8 n \pm 3$, and a set of 285 unique reflections was obtained by considering unobserved those having $I<3 \sigma(I)$ and averaging equivalents.

The unit cell parameters obtained through least-squares fit of $2 \theta$ values of a set of accurately centred reflections were: $a=10.865(4), b=$ 4.006(2), $c=7.233(3) \AA, \beta=117.24(4)^{\circ}$. The starting coordinates for $\mathrm{Pb}, \mathrm{Cl}$ and $\mathrm{O}$ were obtained from those given by Ventopoulos and Rentzeperis (1975) for laurionite by means of the transformation matrix $[100 / 010 /-0.7744,0,1]$, after changing the origin. Therefore, given $x_{o}, y_{o}, z_{o}$ the atomic coordinates for laurionite, those for paralaurionite may be obtained as follows:

$$
\begin{aligned}
& x_{m}=x_{o}-1 / 4 \\
& y_{m}=y_{o}-1 / 4 \\
& z_{m}=0.7744 x_{o}+z_{o}-0.3872
\end{aligned}
$$

In fact the displacement of $(1 / 4,1 / 4,0.1936)$ occurs between the origins of laurionite and paralaurionite, located at the inversion centre of the $\mathrm{L}_{0}$ and $\mathrm{L}_{1}$ layers, respectively. Moreover, the vectorial relationships between the unit cell parameters are as follows:

$$
\begin{aligned}
& \mathbf{a}_{m}=\mathbf{a}_{o}-0.7744 \mathbf{c}_{\mathrm{o}} \\
& \mathbf{b}_{m}=\mathbf{b}_{o} \\
& \mathbf{c}_{m}=\mathbf{c}_{o}
\end{aligned}
$$

and the $\beta$ value for the monoclinic cell is: 


$$
\beta_{m}=90^{\circ}+\arctan \left(0.7744 c_{o} / a_{o}\right)
$$

The isotropic refinement converged to $R=$ 0.082 . After an empiricial correction for absorption effects through DIFABS (Walker and Stuart, 1983), the refinement was completed using a weighting scheme based on $w=1 /\left[\sigma\left(F_{o}\right)\right]^{2}$ and anisotropic thermal parameters for $\mathrm{Pb}$ and $\mathrm{Cl}$ atoms. The position of the hydrogen was computed assuming a regular tetrahedral environment for the oxygen atom by fixing the proper distances and angles, but the hydrogen atom was not introduced in the least-square calculations, which were carried out by means of the SHELX76 program (Sheldrick, 1976). The final reliability indices were $R=0.062$ and $R_{w}=0.048$. Final fractional coordinates and thermal parameters are reported in Table 1. A supplementary table of observed and calculated structure factors is available from one author (M. P.) on request.

\section{Description of the structure}

The bonding in paralaurionite is identical, at least in the general geometry of the first coordina- tions, to that of laurionite (Cannillo et al., 1969; Venetopoulos and Rentzeperis, 1975), even if some differences exist between corresponding distances in the two structures (Table 2). Lead is linked to $5 \mathrm{Cl}^{-}$and $3(\mathrm{OH})^{-}$anions; the $\mathrm{Pb}$ centred polyhedron may be described as a distorted square antiprism as well as a bicapped triangular prism. In both laurionite and paralaurionite these polyhedra form infinite columns running along $\mathbf{b}$, by sharing the basal triangular faces. The chlorine atom is bonded to $5 \mathrm{~Pb}$ atoms which form a distorted rectangular pyramid. The oxygen atom lies at the centre of a tetrahedron having $3 \mathrm{~Pb}$ atoms and 1 hydrogen at the four vertices. However, the position of the hydrogen has not been found in the final difference Fourier map and, as stated above, has been inferred on crystal-chemical arguments, namely assuming the typical tetrahedral coordination of oxygen observed in laurionite and other lead hydroxychlorides (Merlino et al., in prep.).

By considering the environment of the hydrogen atom, we could suggest $\mathrm{O}-\mathrm{H} \cdots \mathrm{Cl}^{\mathrm{III}}$ and $\mathrm{O}$ $\mathrm{H} \cdot \cdots \mathrm{Cl}^{\mathrm{VII}}$ as the most probable, bifurcated hydrogen bond, as the $\mathrm{O} \cdots \mathrm{O}^{\mathrm{VIII}}$ distance of $3.89 \AA$ is

Table 1. Final fractional coordinates and equivalent isotropic $B_{e q}$ thermal parameters (isotropic $B$ for oxygen) for paralaurionite. The coordinates are compared with those computed from the refinement of laurionite.

\begin{tabular}{|c|c|c|c|c|}
\hline & & 1 & 2 & 3 \\
\hline $\mathrm{Pb}$ & $\begin{array}{l}x \\
y \\
z \\
B_{e q}\end{array}$ & $\begin{array}{l}0.41230 \\
1 / 4 \\
0.29736\end{array}$ & $\begin{array}{l}0.1623 \\
0 \\
0.2294\end{array}$ & $\begin{array}{l}0.1719(1) \\
0 \\
0.2408(2) \\
0.81(3)\end{array}$ \\
\hline $\mathrm{Cl}$ & $\begin{array}{l}x \\
y \\
z \\
B_{e q}\end{array}$ & $\begin{array}{l}0.6798 \\
1 / 4 \\
0.0564\end{array}$ & $\begin{array}{l}0.4298 \\
0 \\
0.1956\end{array}$ & $\begin{array}{l}0.4332(8) \\
0 \\
0.191(1) \\
1.7(3)\end{array}$ \\
\hline $\mathrm{O}$ & $\begin{array}{l}x \\
y \\
z \\
B\end{array}$ & $\begin{array}{l}0.4578 \\
1 / 4 \\
0.622\end{array}$ & $\begin{array}{l}0.2078 \\
0 \\
0.589\end{array}$ & $\begin{array}{l}0.198(2) \\
0 \\
0.591(3) \\
1.2(4)\end{array}$ \\
\hline $\mathbf{H}$ & $\begin{array}{l}x \\
y \\
z\end{array}$ & $\begin{array}{l}0.390 \\
1 / 4 \\
0.723\end{array}$ & $\begin{array}{l}0.140 \\
0 \\
0.638\end{array}$ & $\begin{array}{l}0.108 \\
0 \\
0.590\end{array}$ \\
\hline
\end{tabular}

1. Fractional coordinates of laurionite from Venetopoulos and Rentzeperis (1975), with choice of an asymmetric unit with $x$ coordinate ranging from 0.25 to 0.75 for all atoms.

2. Starting coordinates for the present refinement, obtained from 1 . through transformations given in the text.

3. Refined fractional coordinates and thermal parameters for paralaurionite. 
Table 2. Interatomic distances $(\AA)$ in paralaurionite (first column), compared with the corresponding distances in laurionite (Venetopoulos and Rentzeperis, 1975; second column). Distances marked with an asterisk occur twice in the same polyhedron.

\begin{tabular}{|c|c|c|c|}
\hline & & ntral atom $P$ & \\
\hline $\mathrm{Pb}$ & $-\mathrm{Cl}$ & $3.020(10)$ & $3.112(4)$ \\
\hline & $-\mathrm{Cl}$ & $3.165(7)^{*}$ & $3.197(3)$ \\
\hline & - ClII & $3.437(7)^{*}$ & $3.344(3)$ \\
\hline & -0 & $2.414(27)$ & $2.355(1)$ \\
\hline & - OHI & $2.431(11)^{*}$ & $2.441(7)$ \\
\hline $\mathrm{Cl}$ & - CliI & $4.175(9)^{*}$ & $4.108(5)$ \\
\hline & - OIII & $3.256(26)^{*}$ & $3.325(12)$ \\
\hline Cli & $-\mathrm{ClII}$ & $3.665(15)^{*}$ & $3.812(6)$ \\
\hline & - Cliv & $4.006(2)^{*}$ & $4.020(3)$ \\
\hline & -0 & $3.612(17)^{*}$ & $3.598(11)$ \\
\hline & - Oili & $3.569(26)^{*}$ & $3.549(13)$ \\
\hline Clı & $-\mathrm{OHII}^{\mathrm{n}}$ & $3.901(22)^{*}$ & $3.767(12)$ \\
\hline 0 & - O"1 & $2.891(32)^{*}$ & $2.784(15)$ \\
\hline & $\ldots$ Clir & 3.256 & \\
\hline & & 0.98 & \\
\hline $\mathrm{H} \ldots$ & $\mathrm{Cl}$ & 2.72 & \\
\hline
\end{tabular}

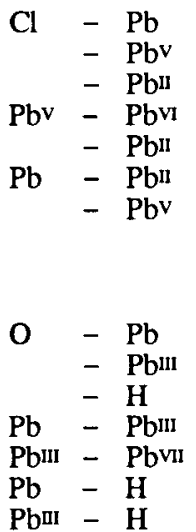

Central atom $\mathrm{Cl}$

$\begin{array}{ll}3.020(10) & 3.112(4) \\ 3.165(7)^{*} & 3.197(3) \\ 3.437(7)^{*} & 3.344(3) \\ 4.006(2)^{*} & 4.020(1) \\ 3.765(3)^{*} & 4.754(1) \\ 4.943(3)^{*} & 4.987(1) \\ 5.790(4)^{*} & 5.297(1)\end{array}$

Central atom $\mathrm{O}$

$\begin{array}{ll}2.414(27) & 2.355(1) \\ 2.431(11)^{*} & 2.441(7) \\ 0.98 & 0.97 \\ 3.889(2)^{*} & 3.907(1) \\ 4.006(2) & 4.020(1) \\ 2.91 & 3.04 \\ 2.92^{*} & 2.78\end{array}$

Symmetry code for equivalent positions: $\mathrm{I}: x-1 / 2, y+1 / 2, z ; \mathrm{11}:-x+1 / 2, y+1 / 2,-z ; \quad \mathrm{III}:-x+1 / 2, y+1 / 2,-z+1$; Iv: $x-1 / 2, y-1 / 2, z ;$ v: $x+1 / 2, y+1 / 2, z ;$ и: $x+1 / 2, y-1 / 2, z ;$ иг: $-x+1 / 2, y-1 / 2,-z+1 ;$ vir: $-x, y,-z+1$.

obviously too great for a hydrogen bond. The corresponding $\mathrm{O}-\mathrm{H} \cdots \mathrm{Cl}$ bond angles are about $115^{\circ}$. Such a value could appear too small and, as an alternative hypothesis, it is possible that the hydrogen atom leaves the symmetry plane, giving rise to normal hydrogen bonds with either of the two chlorine atoms.

Interesting and significant differences between laurionite and paralaurionite appear in the connection of polyhedra between each other. If we look at the coordination polyhedra around lead as a bicapped triangular prism, we can see that in laurionite the columns of such polyhedra give rise to infinite chains running along $\mathbf{c}$, by sharing $\mathrm{Cl}-$ $\mathrm{Cl}$ edges with neighbouring columns. Contrarily, in paralaurionite pairs of columns share 'square' faces between each other and no chains along $\mathbf{c}$ occur. The face-sharing causes remarkable differences among corresponding distance in the two structures. The $\mathrm{Cl}^{\mathrm{I}}-\mathrm{Cl}^{\mathrm{II}}$ edge is $3.665 \AA$ long in paralaurionite, whereas it is $3.812 \AA$ long in laurionite; in fact $\mathrm{Cl}^{\mathrm{I}}-\mathrm{Cl}^{\mathrm{II}}$ represents one of the two independent $\mathrm{Cl}-\mathrm{Cl}$ distances in the shared face (the other one, $\mathrm{Cl}^{1}-\mathrm{Cl}^{\mathrm{IV}}$, is constrained to be identical to the $b$ cell parameter), and the reduction of the $\mathrm{Cl}-\mathrm{Cl}$ distance accomplishes the tendency for $\mathrm{Pb}$ atoms to lie as far as possible between each other without major variations in the $\mathrm{Pb}-\mathrm{Cl}$ bond distances; this results in a lengthening of the $\mathrm{Pb}-\mathrm{Pb}$ distance across the shared face from $3.48 \AA$ (in hypothetical undistorted pairs of polyhedra) to actual $3.765 \AA$.

Similarly remarkable differences may be found in chlorine coordination, which is described in laurionite by Venetopoulos and Rentzeperis (1975) in terms of rectangular pyramids [ClPb 5$]$. The corresponding polyhedron in paralaurionite presents the previously discussed $\mathrm{Pb}^{\mathrm{V}}-\mathrm{Pb}^{\mathrm{II}}$ distance of $3.765 \AA$ instead of $4.754 \AA$ and an 'apical' $\mathrm{Pb}$ definitely displaced from a central position, resulting in a long $\mathrm{Pb}-\mathrm{Pb}^{\mathrm{V}}$ edge of $5.790 \mathrm{~A}$ instead of $5.297 \AA$.

Paralaurionite is an example of strong desymmetrisation (Durovič, 1979), as face-sharing of lead polyhedra and consequent shortening of $\mathrm{Cl}^{1}-$ $\mathrm{Cl}^{\mathrm{II}}$ edges results in deviations from the $\mathrm{OD}$ symmetry of the $\mathrm{Cl}$ layers, which assume an actual symmetry $P$ (1) $2 / m 1$ to compare with the idealised $P(2 / c) 2 m 2 / m$. The desymmetrisation is also responsible for the imperfect match between the cell parameters of the two MDO structures.

Because of their OD character we suggest that laurionite and paralaurionite are denoted laurionite- $2 O$ and laurionite- $2 M$ respectively, at least whenever their polytypic relationships are described and discussed. This is in keeping with the suggestions of Nickel and Mandarino (1987) on 
the nomenclature of polytype structures, as laurionite, $\mathrm{MDO}_{1}$, contains two layers of each type in the orthorhombic unit cell, whereas paralaurionite, $\mathrm{MDO}_{2}$, contains two layers of each type in the monoclinic unit cell.

\section{Acknowledgement}

Financial support by Centro di Studi per la Geologia Strutturale e Dinamica dell'Appennino (C.N.R., Pisa) and by M.U.R.S.T. ( $40 \%$ grant to S. Merlino) is acknowledged. The paper benefited from a review by an anonymous referee.

\section{References}

Arzruni, A. and Thaddéeff, K. (1899) Neue Minerale aus Chile, ein neues Vorkommen von Utahit und ein neues Wismuthcarbonat von Schneeberg. Z. Kristallogr., 31, 229-47.

Brasseur, H. (1940) Etude roentgenographique de la laurionite PbOHCl. Bull. Soc. Roy. Sci. Liège, 9, 166-9.

Cannillo, E., Giuseppetti, G., and Tadini, C. (1969) Riesame della struttura della laurionite $\mathrm{PbOHCl}$. Per. Mineral., 38, 395-402.

Dornberger-Schiff, K. (1964) Grundzüge einer Theorie der OD Strukturen aus Schichten. Abh. Dtsch. Akad. Berlin, Kl. Chem. Geol. Biol., no. 3.

- (1966) Lehrgang über OD-Strukturen. AkademieVerlag, Berlin, $135 \mathrm{pp}$

(1967) On the relation between the monoclinic and the orthorhombic form of yttrium hydroxychloride, $\left[\mathrm{YCl}(\mathrm{OH})_{2}\right]_{n}$. Acta Crystallogr., 22, 435-6.

(1982) Geometrical properties of MDO polytypes and procedures for their derivation. I. General concept and application to polytype families consisting of OD layers all of the same kind. Ibid., A38, 483-91.

and Grell, H. (1982) Geometrical properties of MDO polytypes and procedures for their derivation. II. OD families containing OD layers of $M>1$ kinds and their MDO polytypes. Ibid., A38, 491-8.

Durovič, S. (1979) Desymmetrization of OD structures. Krist. Techn., 14, 1047-53.

Franzini, M., Perchiazzi, N., Bartoli, M. L., and Chiappino, L. (1992) Baratti, una nuova località mineralogica simile al Laurion. Riv. Mineral. It., 23, $1-14,67-75$.
Goldsztaub, St. (1937) Structure cristalline de la laurionite. C.R. Acad. Sci. Paris, 204, 702-3.

(1939) Arrangement des atomes dans la laurionite. Ibid., 208, 1234-5.

Grell, H. and Dornberger-Schiff, K. (1982) Symbols of OD groupoid families referring to OD structures (polytypes) consisting of more than one kind of layer. Acta Crystallogr., A38, 49-54.

Köchlin, R. (1887) Über Phosgenit und ein muthmasslich neues Mineral vom Laurion. Ann. Naturhist. Hofmuseums Wien, ser. II, 2, 185-90.

Merlino, S. (1990) OD structures in mineralogy. Per. Mineral., 59, 69-92.

Orlandi, P., Perchiazzi, N., Basso, R., and Palenzona, A. (1989) Polytypism in stibivanite. Can. Mineral., 27, 625-32.

Nickel, E. H. and Mandarino, J. A. (1987) Procedures involving the IMA Commission on New Minerals and Mineral Names and guidelines on mineral nomenclature. Amer. Mineral., 72, 1031-49.

Palache, C. (1934) The form relations of the lead oxychlorides, laurionite, paralaurionite, and fiedlerite. Mineral. Mag., 23, 573-86.

-(1950) Paralaurionite. Ibid., 29, 341-5.

- Berman, H., and Frondel, C. (1951) Dana's system of mineralogy. Vol. II. 7th ed. New York, John Wiley and Sons, $1124 \mathrm{pp}$.

vom Rath, G. (1887) Einige mineralogische und geologische Mittheilungen. Sitzungsber. Niederrhein. Gesell. Nature Bonn, 102, 149-51.

Russell, A. (1928) On laurionite and associated minerals from Cornwall. Mineral. Mag., 21, 221-8.

Sheldrick, G. M. (1976) SHELX76-Program for crystal structure determination. Univ. of Cambridge, England.

Smith, G. F. H. (1899a) On some lead minerals from Laurium, namely, laurionite, phosgenite, fiedlerite, and (new species) paralaurionite. Mineral. Mag., 12, $102-10$.

- $(1899 b)$ Note on the identity of paralaurionite and rafaelite. Ibid., 12, 183.

Venetopoulos, C. Ch. and Rentzeperis, P. J. (1975) The crystal structure of laurionite, $\mathrm{Pb}(\mathrm{OH}) \mathrm{Cl}$. Z. Kristallogr., 141, 246-59.

Walker, N. and Stuart, D. (1983) An empirical method for correcting of diffractometer data for absorption effects. Acta Crystallogr., A39, 158-66.

[Manuscript received 23 April 1992:

revised 18 September 1992] 